Article

\title{
Investigation of $\mathrm{NiFe}-\mathrm{Based}$ Catalysts for Oxygen Evolution in Anion-Exchange Membrane Electrolysis
}

\author{
Sabrina Campagna Zignani, Massimiliano Lo Faro, Stefano Trocino and \\ Antonino Salvatore Aricò * $\mathbb{D}$ \\ Institute for Advanced Energy Technologies "Nicola Giordano" (ITAE) of the Italian National Research \\ Council (CNR), 98126 Messina, Italy; zignani@itae.cnr.it (S.C.Z.); lofaro@itae.cnr.it (M.L.F.); \\ stefano.trocino@itae.cnr.it (S.T.) \\ * Correspondence: antonino.arico@itae.cnr.it; Tel.: +39 090624237
}

Received: 20 February 2020; Accepted: 2 April 2020; Published: 4 April 2020

check for updates

\begin{abstract}
NiFe electrodes are developed for the oxygen evolution reaction (OER) in an alkaline electrolyser based on an anion exchange membrane (AEM) separator and fed with diluted $\mathrm{KOH}$ solution as supporting electrolyte. This study reports on the electrochemical behaviour of two different $\mathrm{NiFe}$-oxide compositions (i.e., $\mathrm{Ni}_{1} \mathrm{Fe}_{1}$-oxide and $\mathrm{Ni}_{1} \mathrm{Fe}_{2}$-oxide) prepared by the oxalate method. These catalysts are assessed for single-cell operation in an MEA including a Sustainion ${ }^{\mathrm{TM}}$ anion-exchange membrane. The electrochemical polarization shows a current density of $650 \mathrm{~mA} \mathrm{~cm}^{-2}$ at $2 \mathrm{~V}$ and $50{ }^{\circ} \mathrm{C}$ for the $\mathrm{Ni}_{1} \mathrm{Fe}_{1}$ anode composition. A durability test of $500 \mathrm{~h}$ is carried out using potential cycling as an accelerated stress-test. This shows a decrease in current density of $150 \mathrm{~mA} \mathrm{~cm}^{-2}$ mainly during the first $400 \mathrm{~h}$. The performance achieved for the anion-exchange membrane electrolyser single-cell based on the $\mathrm{NiFeO}_{x}$ catalyst appears promising. However, further improvements are required to enhance the stability under these operating conditions.
\end{abstract}

Keywords: oxygen evolution reaction; anion-exchange membranes; alkaline electrolyser; NiFe oxide electrocatalyst; CRM-free

\section{Introduction}

The role of $\mathrm{H}_{2}$ as an energy vector is becoming progressively a solid choice [1]. Although various processes to produce pure $\mathrm{H}_{2}$ are available (i.e., catalytic-, thermal- and electrochemical-based routes) [2-5], research is looking at how to improve the efficiency and reliability of these technologies. Electrolysis of liquid water is one of the most used technologies to produce pure and green $\mathrm{H}_{2}$, but several issues regarding to the use of a highly concentrate caustic solution $(7 \mathrm{M} \mathrm{KOH})$ as liquid electrolyte have hindered its wide use. For example, liquid alkaline electrolyte based electrolysers, using concentrated solution of $\mathrm{KOH}$ or $\mathrm{NaOH}$ [6-10], have shown significant corrosion effects on the hardware. These drawbacks have affected the wide use of this technology. On the other hand, several positive aspects mainly related to the low cost of materials used for the electrodes (i.e., noble metal-free materials) characterize these alkaline systems [11]. A solution to the issues caused by the use of concentrated liquid electrolytes is to develop alkaline electrolysers based on a solid polymer electrolyte separator with a zero gap configuration (membrane-electrode assembly) requiring less concentrated $\mathrm{KOH}$ solution [12].

Several important achievements concerning the electrolysis of liquid water are reported in the literature especially for the use of solid proton-conducting polymer membrane [13-17]. Although this technology sounds to be safer than the liquid alkaline-based electrolyser, issues remain because of materials cost. Nafion $₫$ membrane-based assemblies represent the proof-of-concept for this technology $[7,18]$. As this electrolyte operates under acidic conditions, this implies the use of noble 
materials for the electrodes. This is avoidable under an alkaline environment. Therefore, a technology that may combine the positive aspects of both acidic and alkaline electrolysers is nowadays under investigation. In the meantime, novel types of polymeric membranes characterized by hydroxide ion conductivity have emerged [19-24], although their stability is still an issue. Such electrolytes promise to solve the issues raising from the cost of materials for electrodes and from the use of concentrated liquid alkaline electrolytes [17]. As a result, developing advanced critical raw materials free (CRM-free)-based electrocatalysts has also become an important topic for research $[17,25,26]$. A key aspect in this context is to find a proper oxygen evolution reaction (OER) electrocatalyst for the anionic electrolysers since the kinetics of the anodic reaction are also slow in alkaline conditions [27]. Unsupported iridium-based catalysts represent the state-of-the-art OER catalysts for this technology $[9,28]$. However, iridium is expensive and one of the rarest element on earth [29]. Nickel/iron (NiFe)-based materials have shown good catalytic activity towards OER for many applications [30] and therefore, many synthetic methods are under development [31]. Pérez-Alonso et al. have prepared different Ni/Fe wt.\% compositions for OER. The durability tests carried out at a fixed current density of $300 \mathrm{~mA} \mathrm{~cm}^{-2}$ during $70 \mathrm{~h}$ showed a potential of $2.1 \mathrm{~V}$ for the alkaline water electrolysis cell [32].

Huang et al. [33] have reported the performances of several Ni/Fe oxides prepared from metal hexacyanometallates precursors. They reported a stable anodic overpotential during about $10 \mathrm{~h}$ durability test. They have also shown a relatively low degradation during 1000 current-voltage cycles considered as benchmark for an accelerated stress test.

A review about NiFe-oxides as electrocatalysts for OER was published by Gong and Dai in 2015. They analysed the main properties of these materials in terms of structure and electronic properties and how these catalysts can enhance the oxygen evolution reaction rate [31]. However, most of the reported experiments were regarding half-cell studies [31].

Some recent studies have addressed novel ternary electrocatalysts based on Ni-Fe-M (where $\mathrm{M}$ indicates $\mathrm{Mo}, \mathrm{Cr}, \mathrm{V}, \mathrm{Co}$, etc.). Yang et al. [34] have reported on the promising stability of the Ni-Fe-Cr alloy. Fan et al. [35] have also recently reported on the "ultra-stable performances" of Ni-Fe-V. These works were essentially regarding experiments carried out in half-cell configuration.

Recently Qin et al. [36] have reported on experiments carried out in a complete cell based on $\mathrm{KOH}$ electrolyte. However, this was a non-zero gap cell [36]. By using Ni-Fe-Mo as an electrocatalyst for both HER (hydrogen evolution reaction) and OER, promising performances were achieved [36]. In particular, Ni-Fe-Mo was used both as electrocatalyst for HER and as a "pre-catalyst" for OER.

Chanda et al. [37] have found that by forming a ternary spinel oxide after partial replacement of $\mathrm{Co}$ in the $\mathrm{NiCo}_{2} \mathrm{O}_{4}$ spinel oxide with $\mathrm{Fe}$, an important increase of current density can be achieved.

On the other hand, it has been largely demonstrated that a spinel phase is more performing compared the pure Ni oxide and Fe oxide [38,39].

The outstanding properties of NiFe-oxide catalysts for the oxygen evolution reaction in the alkaline environment, shown in the recent literature, have prompted us to carry an investigation under practical operating conditions by selecting relevant NiFe electrocatalyst formulations. Thus, in the present paper, two compositions of $\mathrm{NiFeO}_{x}$ electrocatalysts for the oxygen evolution reaction in an alkaline environment have been investigated. As discussed, most of the aforementioned work on $\mathrm{Ni} / \mathrm{Fe}$ has been carried out with a three-electrode configuration in alkaline media at room temperature, whereas the present work presents the electrochemical performance achieved in a solid state membrane electrode assembly(zero-gap configuration) single cell operating under real conditions at different temperatures. Operation of an anion exchange membrane electrolyser with pure water feed is at the moment not affordable for the present hydroxide conducting membranes. This will cause large increase of overpotential at practical current density producing large loss of efficiency. Whereas the trend in the field of electrolysis is to increase the operating efficiency and decrease capital costs as well as operating expenditures. A dilute $\mathrm{KOH}$ solution $(1 \mathrm{M})$ may represent a trade-off with respect to these requirements. 
In the present work, we have prepared the $\mathrm{NiFeO}_{x}$ electrocatalysts by using a simple and cost-effective procedure based on the oxalate method [40] which is also amenable to scaling-up. The aim was to assess this preparation procedure as an appropriate method to produce CRM-free anode electrocatalysts suitable for application in AEM electrolysis. In this regard, a standard $\mathrm{Pt}$ cathode for hydrogen evolution was used. The results of the electrochemical experiments have been discussed in relation to the structural, morphological, and chemical surface properties of the developed materials. The presence of different phases on the catalysts surface may affect interaction with water and hydroxide species in solution producing different performance and stability characteristics under practical operating conditions in single cell.

\section{Materials and Methods}

\subsection{Preparation and Physico-Chemical Properties of Non-Precious Catalysts for Alkaline Electrolysis}

This synthetic procedure is referred to the oxalate method (Patent WO2004049491) [13,16]. In brief, $\mathrm{Ni}$ and Fe nitrates (purity $\geq 99.95 \%$ trace metals basis, Sigma-Aldrich, Milano, Italy) have been dissolved in an aqueous solution of oxalic acid (purity $\geq 99 \%$, Merck, Milano, Italy) neutralized at $\mathrm{pH}$ 6.5 with $\mathrm{NaOH}$ (purity $\geq 99 \%$, Merck) to form an organic complex. The subsequent step consisted on its decomposition at $80{ }^{\circ} \mathrm{C}$ with hydrogen peroxide (Sigma-Aldrich) to form a precipitate. The sample was washed with hot water and treated at $450{ }^{\circ} \mathrm{C}$ for $120 \mathrm{~min}$ to achieve a proper morphology and structure.

\subsection{Physico-Chemical Characterizations}

An X-pert $3710 \mathrm{X}$-ray diffractometer (Panalytical Italia, Lissone, Italy) equipped with a $\mathrm{Cu} \mathrm{K} \alpha$ radiation operating at $40 \mathrm{kV}$ and $20 \mathrm{~mA}$ was used to analyse the crystalline phase of the specimens. The crystallite size was determined from the peaks broadening using the Debye-Scherrer equation and the Marquardt algorithm (Table 1). An ASAP 2020 M machine (Micrometrics, Pioltello, Italy) was used to analyse the specific surface area of specimens through the Brunauer-Emmett-Teller (BET) method whereas the pore size distribution was studied through the Barrett-Joyner-Halenda (BJH) method. An XL 30 scanning electron microscope (SEM, FEI, Milano, Italy) equipped with energy dispersive X-ray analysis (EDX) was used to investigate the samples composition. The morphology was studied by transmission electron microscopy (TEM - FEI CM12 equipped with a LaB6 filament). A Physical Electronics 5800-01 spectrometer (PHI, Feldkirchen, Germany) mounting a monochromatic $\mathrm{Al} \mathrm{K \alpha}$ $\mathrm{X}$-ray source was used for the X-ray photoelectron spectroscopy (XPS).

\subsection{Electrodes Preparation and Membrane-Electrode Assembly}

The preparation of catalytic inks consisted in $33 \mathrm{wt}$. \% of anionic ionomer and $67 \mathrm{wt}$. \% of catalyst dispersed in ethanol. The electrodes have been prepared by spray coating the inks based on in-house prepared NiFe anode catalyst-ketjenblack mixture 70:30 wt. \% or the Pt/C catalyst, HISPEC 4000 supplied by Johnson Matthey Fuel Cell (Sonning Common, UK) onto carbon cloth backings (GDL-HT ELAT from ETEK, Natick Massachusetts, USA), according to the procedure reported in our previous paper [17]. Based on this procedure, the total metal loading for the anode was $2.5 \mathrm{mg} \mathrm{cm}^{-2}$, whereas the cathode catalyst loading was $1 \mathrm{mg} \mathrm{Pt} \mathrm{cm}^{-2}$. The Pt-based catalyst was used as a reference cathode since its characteristics are well known and highly reproducible [41,42]. The aim was to study the anode performance in combination with the anion exchange membrane. A Sustainion ${ }^{\mathrm{TM}}$ X37-50 (Dioxide Materials, Champaign, Illinois, USA) anion exchange membrane conducting $\mathrm{OH}^{-}$ions was used. Finally, membrane-electrode assemblies (MEAs), with a geometrical area of $5 \mathrm{~cm}^{2}$ have been prepared by a cold-assembly procedure to avoid any unwanted membrane degradation during hot pressing. 


\subsection{Electrochemical Characterization in an Alkaline Electrolysis Single Cell}

The electrochemical experiments were carried out in a single-cell configuration, in the temperature range $30-60{ }^{\circ} \mathrm{C}$ and under atmospheric pressure. Humidified $\mathrm{N}_{2}$ was pre-heated at the cell temperature and then fed to the cathode compartment at a flow rate of $50 \mathrm{ml} \mathrm{min}^{-1}$. A peristaltic pump was used to

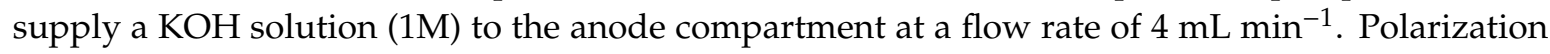
curves (cell potential versus current density) and chronoamperometric curves were carried out with a Keithley power supply system (Tektronic, Roma, Italy) at $10 \mathrm{mV} \mathrm{s}^{-1}$ scan rate. The series resistance $\left(R_{\mathrm{s}}\right)$ was determined using an impedance bridge (4338B, Agilent, Roma, Italia) at a frequency of $1 \mathrm{kHz}$.

\section{Results and Discussion}

\subsection{Physico-Chemical Properties of (CRM)-Free Catalysts for Alkaline Electrolysis}

Figure 1 shows the $\mathrm{X}$-ray diffraction spectrum (XRD) of $\mathrm{NiFeO}_{\mathbf{x}} / \mathrm{KB}$ and $\mathrm{NiFe}_{2} \mathrm{O}_{\mathbf{x}} / \mathrm{KB}$ electrocatalysts. A significant difference in the crystallographic structure has been observed, although both electrocatalysts were treated at the same temperature (i.e., $\left.450{ }^{\circ} \mathrm{C}\right)$. The $\mathrm{NiFeO}_{\mathrm{x}}$ catalyst $(\mathrm{Ni}: \mathrm{Fe}$ $=1: 1$ at.) showed a crystalline structure ascribed to a spinel phase (i.e., JCPDS card $n^{\circ} 10-0325$ of $\mathrm{NiFe}_{2} \mathrm{O}_{4}$ ) although also the presence of $\mathrm{Fe}_{2} \mathrm{O}_{3}$ and $\mathrm{NiO}$ phases (JCPDS cards n ${ }^{\circ}$ 24-0072 and 22-1189, respectively) was recognized. Therefore, the amount of these three main phases was evaluated through the least-square full-profile quantitative analysis procedure. Accordingly, the relative content of the three main phases was $\mathrm{NiO}$ (61.1 wt. \%), $\mathrm{NiFe}_{2} \mathrm{O}_{4}\left(26.3\right.$ wt. \%), and $\mathrm{Fe}_{2} \mathrm{O}_{3}(12.6$ wt. \%). All these phases have been shown to be active towards the oxygen evolution in alkaline solutions [39,43-50]. Their combination may produce a synergistic effect towards the oxygen evolution reaction. On the other hand, the $\mathrm{NiFe}_{2} \mathrm{O}_{x}(\mathrm{Ni}: \mathrm{Fe}=1: 2$ at.) has shown a less crystalline structure with a different phase composition. In this case, the quantitative analysis provided the following composition: $\mathrm{NiO}(26.1 \mathrm{wt}$. $\%), \mathrm{NiFe}_{2} \mathrm{O}_{4}\left(66.8\right.$ wt. \%), and $\mathrm{Fe}_{2} \mathrm{O}_{3}\left(9.7\right.$ wt. \%). As consequence, the $\mathrm{NiFe}_{2} \mathrm{O}_{\mathrm{x}}$ showed an enrichment in trevorite and a significant depletion in hematite and $\mathrm{NiO}$ phases.

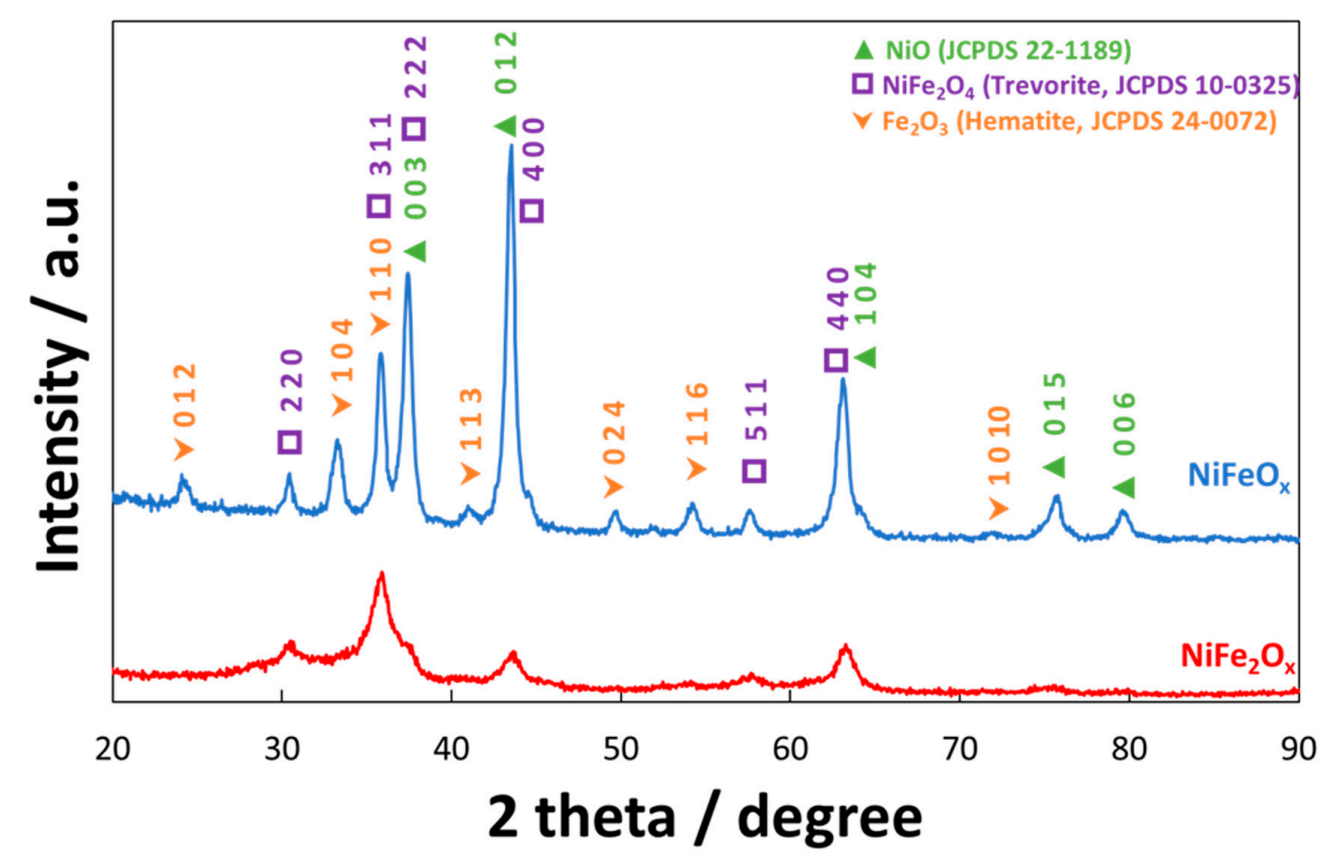

Figure 1. X-ray diffraction patterns of the $\mathrm{NiFe}_{2} \mathrm{O}_{x}$ and $\mathrm{NiFeO}_{x}$ catalysts calcined at $450^{\circ} \mathrm{C}$. The catalyst formulations $\mathrm{NiFe}_{2} \mathrm{O}_{\mathrm{x}}$ and $\mathrm{NiFeO}_{\mathrm{x}}$ refer to a nominal atomic ratio $\mathrm{Ni}$ :Fe equal to 1:2 and 1:1, respectively. 
The EDX analyses (Figure 2) revealed that in the case of $\mathrm{NiFeO}_{x}$ the atomic ratio between the two metals was 1:1; whereas, in the case of $\mathrm{NiFe}_{2} \mathrm{O}_{\mathrm{x}}$, there was an enrichment of Fe with a Ni:Fe ratio close to $1: 2$.

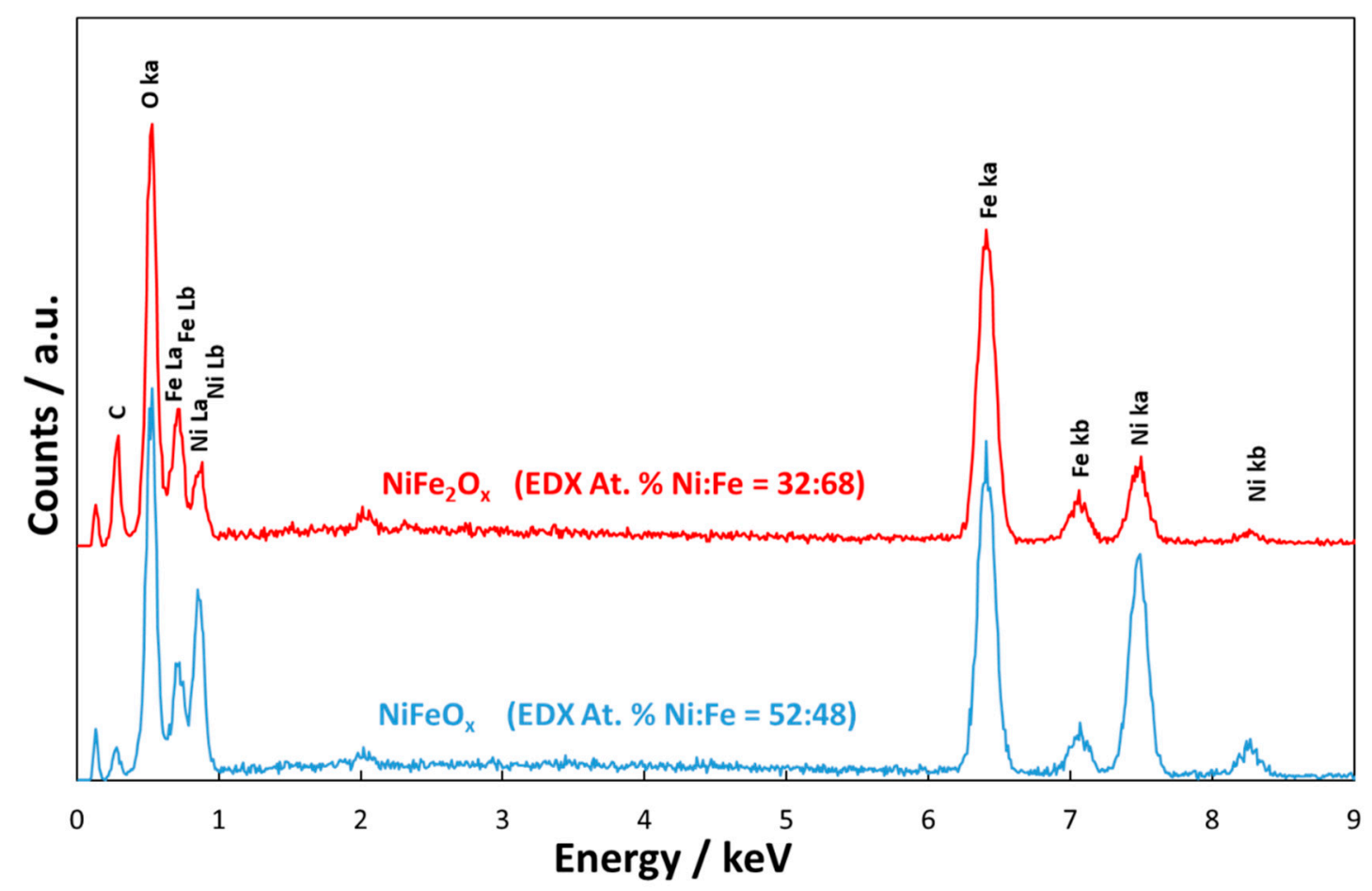

Figure 2. Energy Dispersive X-ray Analysis of the $\mathrm{NiFe}_{2} \mathrm{O}_{\mathrm{x}}$ and $\mathrm{NiFeO}_{\mathrm{x}}$ catalysts calcined at $450{ }^{\circ} \mathrm{C}$. C is related to the carbon tape.

Figure 3 shows the TEM images of the bare catalysts. This analysis shows fine particles with an average crystallite size of about $5 \mathrm{~nm}$ for the $\mathrm{NiFe}_{2} \mathrm{O}_{x}$ and $10 \mathrm{~nm}$ for the $\mathrm{NiFeO}_{\mathrm{x}}$. A high grade of agglomeration for both specimens is observed, although the $\mathrm{NiFeO}_{\mathrm{x}}$ seems to be slightly less agglomerated.
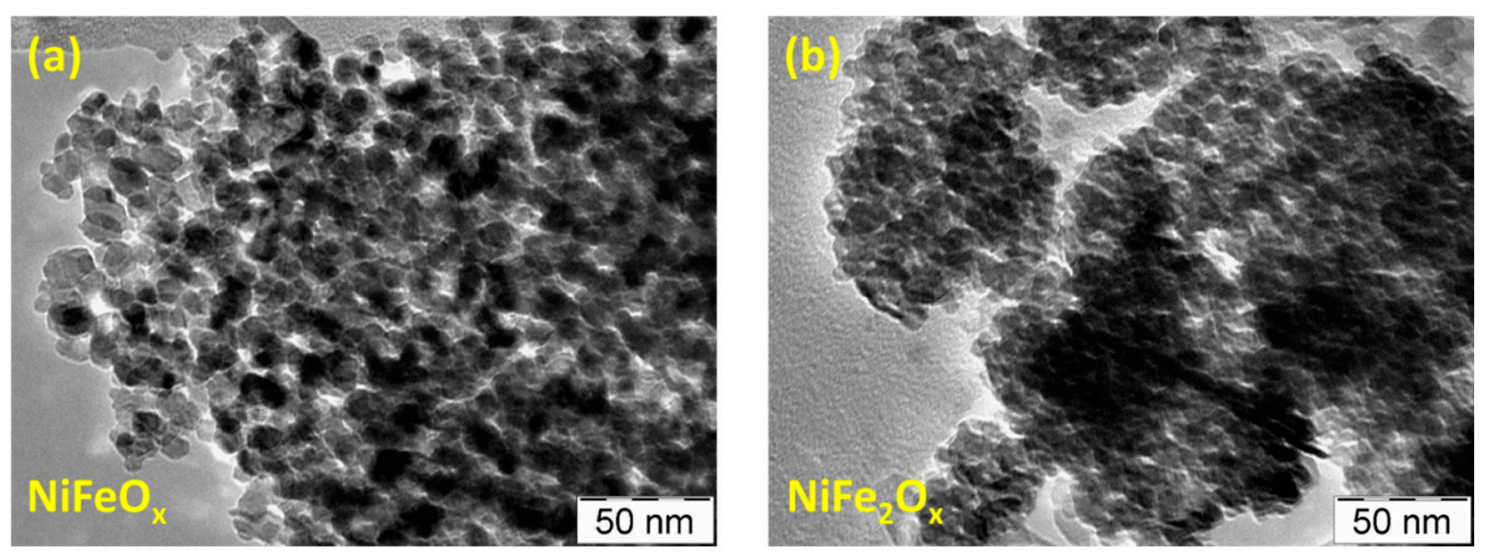

Figure 3. TEM images of the $\mathrm{NiFeO}_{\mathbf{x}}(\mathbf{a})$ and $\mathrm{NiFe}_{2} \mathrm{O}_{\mathbf{x}}(\mathbf{b})$ catalysts.

Table 1 reports the main physico-chemical properties determined from XRD, TEM, BET characterizations. 
Table 1. Structural characteristics of the non-CRM Ni-Fe electrocatalysts.

\begin{tabular}{ccccc}
\hline Catalyst Formula & $\begin{array}{c}\text { Concentration of } \\
\text { Metal Oxide \% }\end{array}$ & $\begin{array}{c}\text { Crystallite Size } \\
(\mathbf{n m}) \mathbf{X R D}\end{array}$ & $\begin{array}{c}\text { Particle Size (nm) } \\
\text { TEM }\end{array}$ & BET $^{\left(\mathbf{m}^{\mathbf{2}} \mathbf{g r}^{-\mathbf{1}}\right)}$ \\
\hline $\mathrm{NiFeO}_{\mathrm{x}} / \mathrm{KB}$ & 70 & 12 & 10 & 50 \\
\hline $\mathrm{NiFe}_{2} \mathrm{O}_{\mathrm{x}} / \mathrm{KB}$ & 70 & 5 & 5 & 141 \\
\hline
\end{tabular}

Figures $4-6$ show a surface characterization of the bare NiFe samples carried out by X-ray photoelectron spectroscopy (XPS). The survey analysis (Figure 4) has shown similar electronic surface composition for both $\mathrm{NiFeO}_{x}$ and $\mathrm{NiFe}_{2} \mathrm{O}_{\mathrm{x}}$. Furthermore, the surface of calcined catalysts has not shown any relevant impurities. On the other hand, the signals ascribed to Ni2p have shown relevant differences between the two specimens (Figure 5). The deconvolution of the asymmetric peak at around $855 \mathrm{eV}$ associated to the $\mathrm{Ni}_{2} \mathrm{p}_{3 / 2}$ orbital has generated two peaks at $853.85 \mathrm{eV}$ (band I) and at $855.42 \mathrm{eV}$ (band II) and these have been ascribed to $\mathrm{NiFe}_{2} \mathrm{O}_{4}$ and $\mathrm{NiO}$, respectively [14]. Although both compounds contain mainly $\mathrm{Ni}^{2+}$, the peak of $\mathrm{Ni}_{2} \mathrm{p}_{3 / 2}$ for the $\mathrm{NiFe}_{2} \mathrm{O}_{4}$ is shifted to lower binding energy as consequence of the presence of larger content $\mathrm{Fe}$ which is less electronegative compared to the Ni. This may have an impact on the intrinsic catalytic activity. Therefore, by comparing the Ni2 $p_{3 / 2}$ bands for the two specimens under investigation, there is a clear enrichment of $\mathrm{NiO}$ on the surface of the $\mathrm{NiFeO}_{\mathrm{x}}$ based specimen (Figure 5), as recognized also by XRD analysis (Figure 1). Concerning the bands ascribed to Fe2p (Figure 6, there is no relevant difference in the surface composition for both specimens.

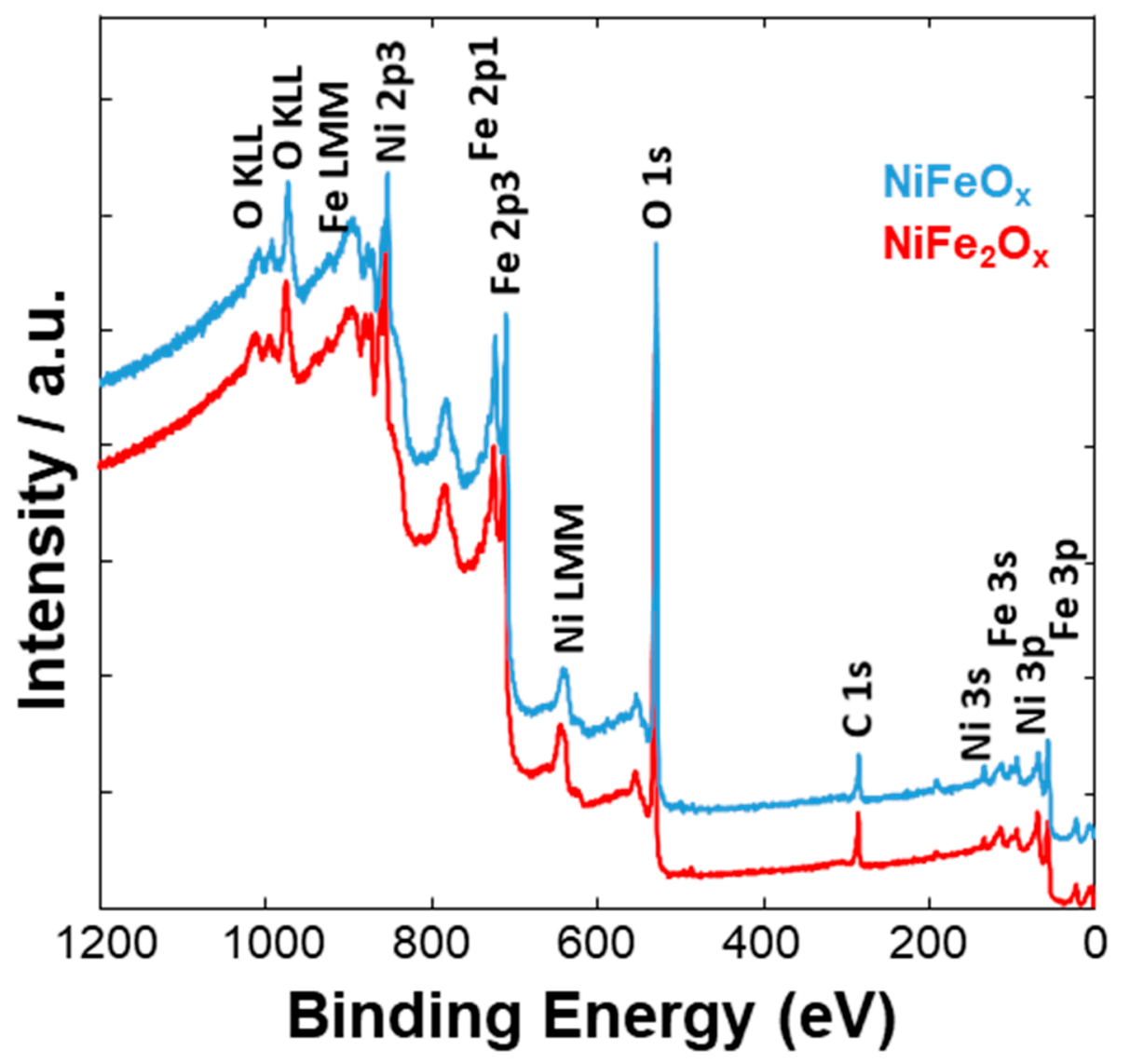

Figure 4. XPS survey analysis of the NiFe-oxide catalysts. 


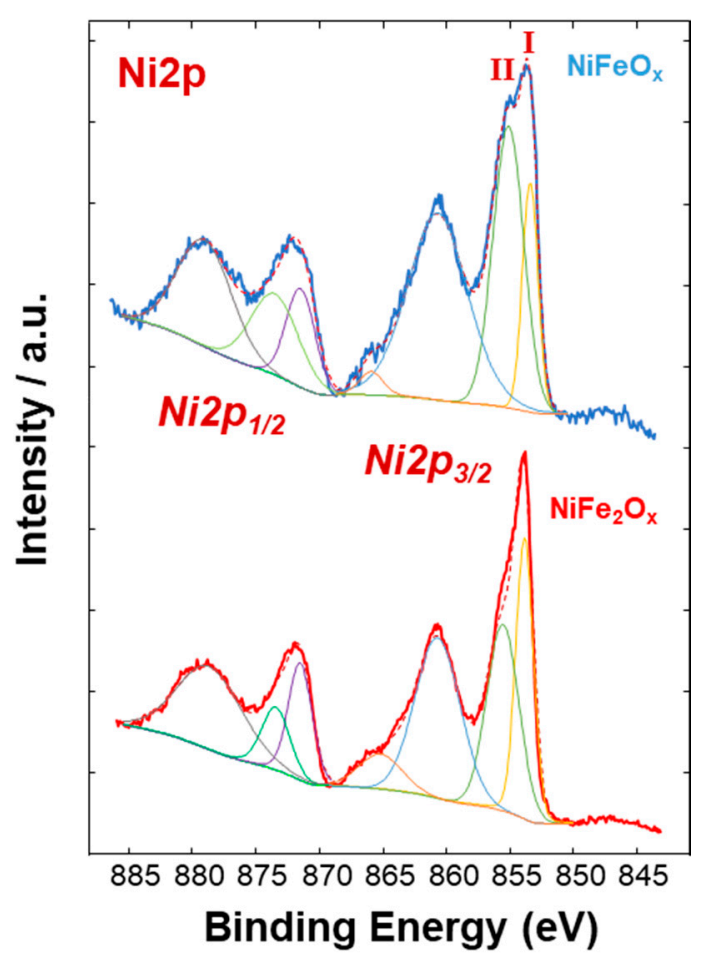

Figure 5. Ni2p XPS signals of the NiFe-oxide catalysts.

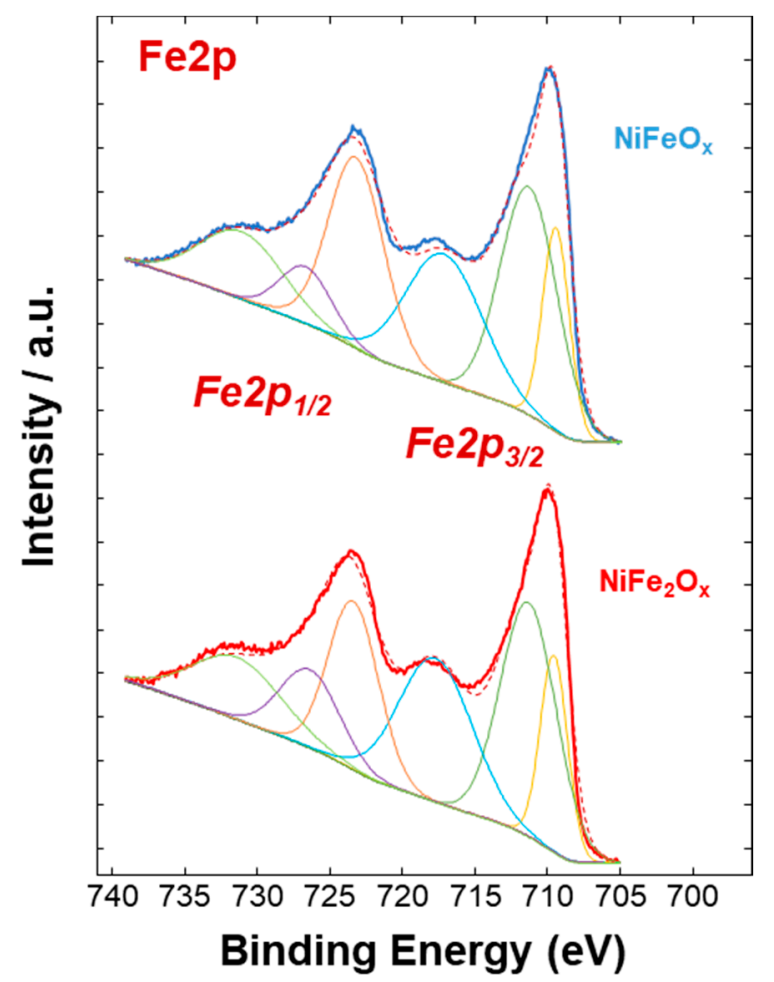

Figure 6. Fe2p XPS signals of the NiFe-oxide catalysts.

\subsection{Electrochemical Experiments}

Figure 7a shows the raw single cell polarization curves for the electrolysis process at a membrane-electrode assembly based on the $\mathrm{Ni}_{1} \mathrm{Fe}_{1}$-oxide catalyst as anode. Figure $7 \mathrm{~b}$ shows the same curves IR-corrected. Experiments were carried out in a single cell with recirculation of $\mathrm{KOH} 1 \mathrm{M}$ at the 
anode (Figure $7 \mathrm{c}$ ) and in the temperature range $30-60^{\circ} \mathrm{C}$. As discussed, recirculation of diluted $\mathrm{KOH}$ in AEM electrolysers avoids dramatic loss of efficiency that would otherwise occur with pure water feed. On the other hand, concentrated $\mathrm{KOH}$ feed can exacerbate membrane degradation. $1 \mathrm{M} \mathrm{KOH}$ was considered as a trade-off between these two effects [51].
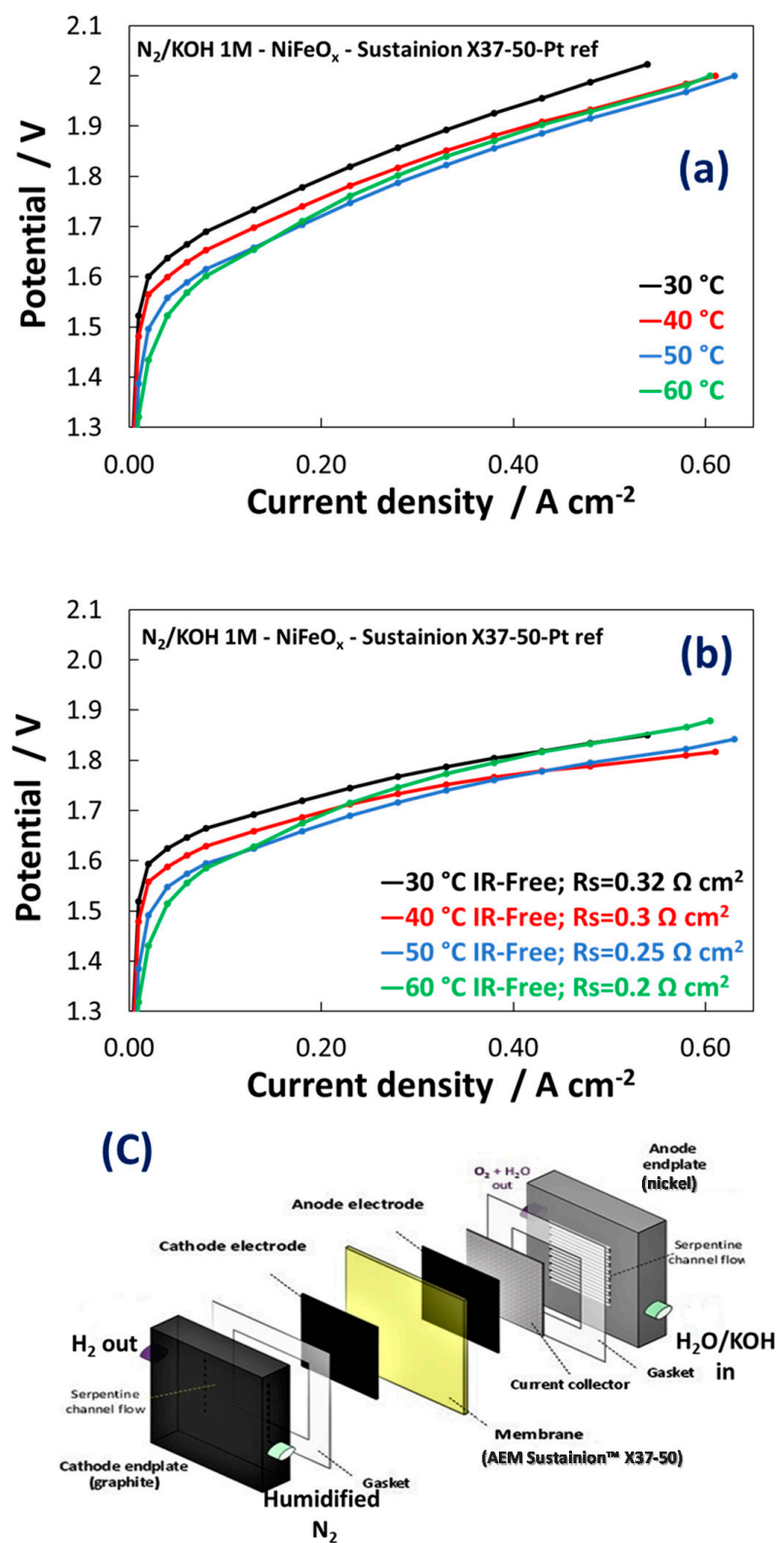

Figure 7. (a) Polarization curves carried out at $1 \mathrm{M} \mathrm{KOH}$ for MEAs including the $\mathrm{NiFeO}_{\mathrm{x}}$-based electrocatalysts at the anode; (b) IR-free polarisation curves; (c) Schematic illustration of the AEM electrolysis cell used in these experiments.

The polarization curves in Figure 7a show an activation control (Butler-Volmer behaviour) up to $50 \mathrm{~mA} \mathrm{~cm}{ }^{-2}$. At higher current density, the polarization curves were controlled by the ohmic drop showing a linear dependence of the potential as function of current density in a wide range. The $\mathrm{NiFeO}_{x} \mathrm{~KB}(1: 1)$ catalyst showed an increase in performance with an increase of temperature because of the kinetic constraints observed especially at low current densities. At $50 \mathrm{~mA} \mathrm{~cm}^{-2}$ the cell voltage decreased by more than $100 \mathrm{mV}$ passing from $30^{\circ} \mathrm{C}$ to $60^{\circ} \mathrm{C}$. In contrast, the increase of temperature affected only slightly the ohmic loss (Figure $7 \mathrm{~b}$ ). This because the membrane ionic resistance was almost constant in the temperature range investigated. The slope of the curves was 
constant between 50 and $600 \mathrm{~mA} \mathrm{~cm}^{-2}$. However, the membrane resistance played a relevant role in determining the voltage efficiency. The voltage gain was more than $100 \mathrm{mV}$ at $0.6 \mathrm{~A} \mathrm{~cm}^{-2}$ in the IR-free curves. Although the increased temperature seems to affect positively the catalytic reactions on both electrodes, the anionic membrane generally suffers during operation temperatures close or higher than $60^{\circ} \mathrm{C}$ because of degradation issues [52-54]. As a result, the best performance in this work has been achieved at $50{ }^{\circ} \mathrm{C}$ whereas at $60^{\circ} \mathrm{C}$ a slight decrease in performance starting from $100 \mathrm{~mA} \mathrm{~cm}^{-2}$ has been observed. The MEA containing the $\mathrm{NiFe}_{2} \mathrm{O}_{\mathrm{x}}(\mathrm{Ni}: \mathrm{Fe}=1: 2)$ catalyst at the anode showed a different polarization behaviour with strong activation control in the overall range of current densities and larger series resistance compared to the MEA based on $\mathrm{NiFeO}_{x}(\mathrm{Ni}: \mathrm{Fe}=1: 1)$.

The activation control indicates poor reaction kinetics (Figure 8a,b). Much lower performances have been achieved for $\mathrm{NiFe}_{2} \mathrm{O}_{x}$ vs $\mathrm{NiFeO}_{x}$ in the temperatures range here investigated. The main difference between the polarization curves of $\mathrm{NiFeO}_{x}$ and $\mathrm{NiFe}_{2} \mathrm{O}_{x}$ concerns with a strong activation control observed for the composition enriched in the spinel structure compared to that enriched in $\mathrm{NiO}$. This may be related to the different absorption strength of oxygen species on the surface and the synergistic role of the different phases. As a result, the $\mathrm{NiFe}_{2} \mathrm{O}_{x}$ containing large excess of spinel phase is less active than the $\mathrm{NiFeO}_{x}$ towards the OER. The $\mathrm{NiFe}_{2} \mathrm{O}_{x}$ shows a slight shift of the $\mathrm{Ni}_{3 / 2}$ to lower binding energy possibly causing an increase of the strength of adsorption of oxygen species with a decrease of the rate of desorption of $\mathrm{O}_{2}$ molecules.
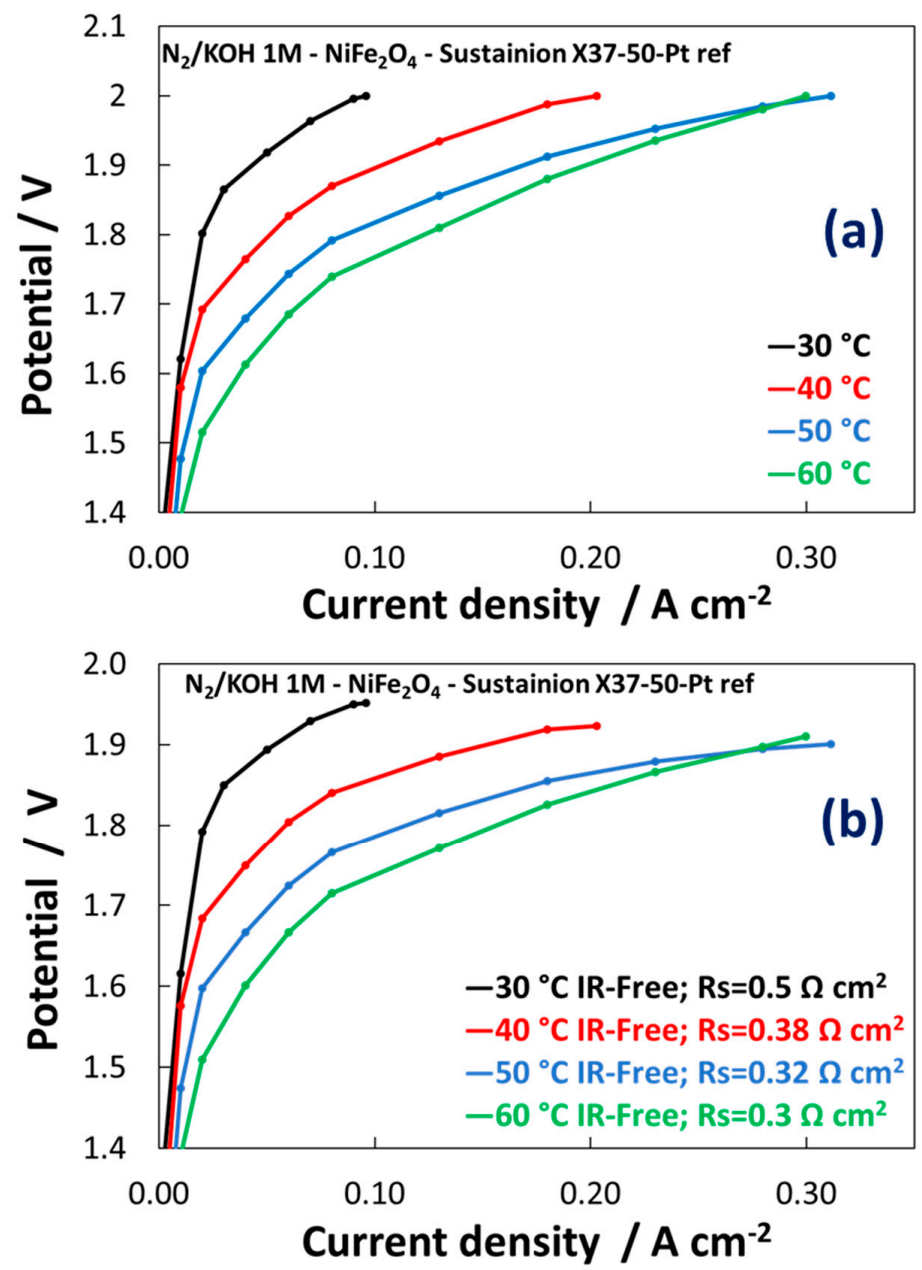

Figure 8. Polarization curves carried out at $1 \mathrm{M} \mathrm{KOH}$ for MEAs including the $\mathrm{NiFe}_{2} \mathrm{O}_{\mathrm{x}}$-based electrocatalysts at the anode. (a) Polarisation curves; (b) IR-free polarization curves. 
The $\mathrm{NiFeO}_{x}$ is instead characterized by a proper content of $\mathrm{NiO}$ compared to $\mathrm{NiFe}_{2} \mathrm{O}_{x}$ and $\mathrm{Fe}_{2} \mathrm{O}_{3}$ phases. $\mathrm{NiO}$ is a good catalyst for oxygen evolution in alkaline systems [55]. Its synergy with the spinel phase appears relevant to promote the OER process under practical conditions.

The performance of the present $\mathrm{NiFeO}_{x}$ catalyst synthesized by the oxalate method appears superior than what has been previously reported in the literature for NiFe catalyst formulations in an alkaline water electrolysis cell [32]. A cell potential of $1.78 \mathrm{~V}$ is here recorded versus $2.1 \mathrm{~V}$ shown in the literature at $300 \mathrm{~mA} \mathrm{~cm}^{-2}$ [32]. This corresponds to a gain of $13 \%$ in terms of voltage efficiency.

Table 2 resumes the mass activities achieved at $1.5 \mathrm{~V}$. At this potential the reactions are mainly affected by the kinetic control, as a result the best performances have been achieved at $60{ }^{\circ} \mathrm{C}$ (the highest temperature).

Table 2. In-situ mass activity for the $\mathrm{NiFeO}_{\mathrm{x}} / \mathrm{KB}$ and $\mathrm{NiFe}_{2} \mathrm{O}_{\mathrm{x}} / \mathrm{KB}$ catalysts with the Sustainion $^{\mathrm{TM}}$ membrane.

\begin{tabular}{|c|c|c|c|c|c|}
\hline Catalyst Formula & Conditions & $\begin{array}{c}30{ }^{\circ} \mathrm{C} \\
\mathrm{A} \mathrm{g}^{-1}{ }_{\mathrm{NiFe}}^{@} 1.5 \mathrm{~V}\end{array}$ & $\begin{array}{c}40{ }^{\circ} \mathrm{C} \\
\mathrm{A} \mathrm{g}^{-1}{ }_{\mathrm{NiFe}}^{@} 1.5 \mathrm{~V}\end{array}$ & $\begin{array}{c}50{ }^{\circ} \mathrm{C} \\
\mathrm{A} \mathrm{g}^{-1}{ }_{\mathrm{NiFe}} @ 1.5 \mathrm{~V}\end{array}$ & $\begin{array}{c}60{ }^{\circ} \mathrm{C} \\
\mathrm{A} \mathrm{g}^{-1} \mathrm{NiFe} @ 1.5 \mathrm{~V}\end{array}$ \\
\hline $\mathrm{NiFeO}_{x} \mathrm{~KB}(70: 30)$ & $1 \mathrm{M} \mathrm{KOH}$ & 4 & 8 & 16 & 24 \\
\hline $\mathrm{NiFe}_{2} \mathrm{O}_{x} \mathrm{~KB}(70: 30)$ & $1 \mathrm{M} \mathrm{KOH}$ & 4 & 4 & 4 & 8 \\
\hline
\end{tabular}

Based on these preliminary experiments, the $\mathrm{NiFeO}_{x}$ has been selected for a durability cycle $(1-1.8 \mathrm{~V})$ test of $500 \mathrm{~h}$. The potential cycling experiment represents an accelerated stress test to evaluate the dynamic behaviour which is required to an electrolysis device in grid balancing service to convert the surplus of renewable energy in hydrogen. A life-time test has been carried out for 500 hours through the potential cycling between $1-1.8 \mathrm{~V}$ at room temperature and by feeding $\mathrm{KOH} 1 \mathrm{M}$ at the anode. As shown in Figure 9a, the maximum current density was more than halved during the stress test. Some discontinuities, essentially related to the replenishment of fresh $\mathrm{KOH}$, have affected the experiment. However, the trend of performance loss was clear during the first $400 \mathrm{~h}$. Figure $9 \mathrm{~b}$ shows the polarization curves before and after the life-time test. Based on the differences found in the polarization curves, the degradation is mainly ascribed to the catalyst (increase of the activation loss), whereas the ohmic drop was not significantly affected by the stress test.

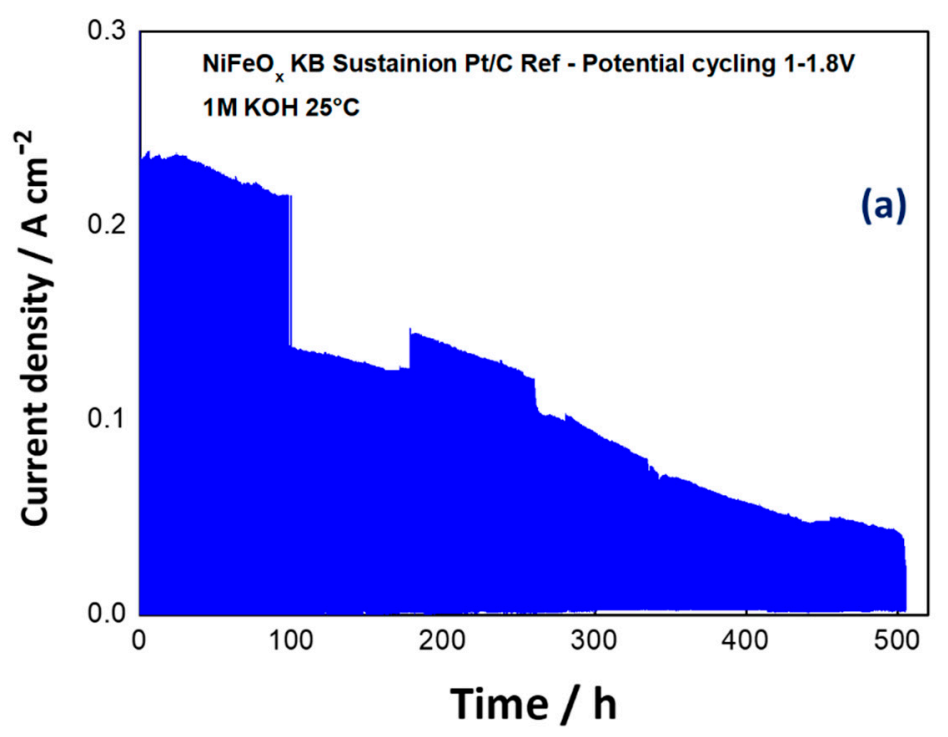

(a)

Figure 9. Cont. 


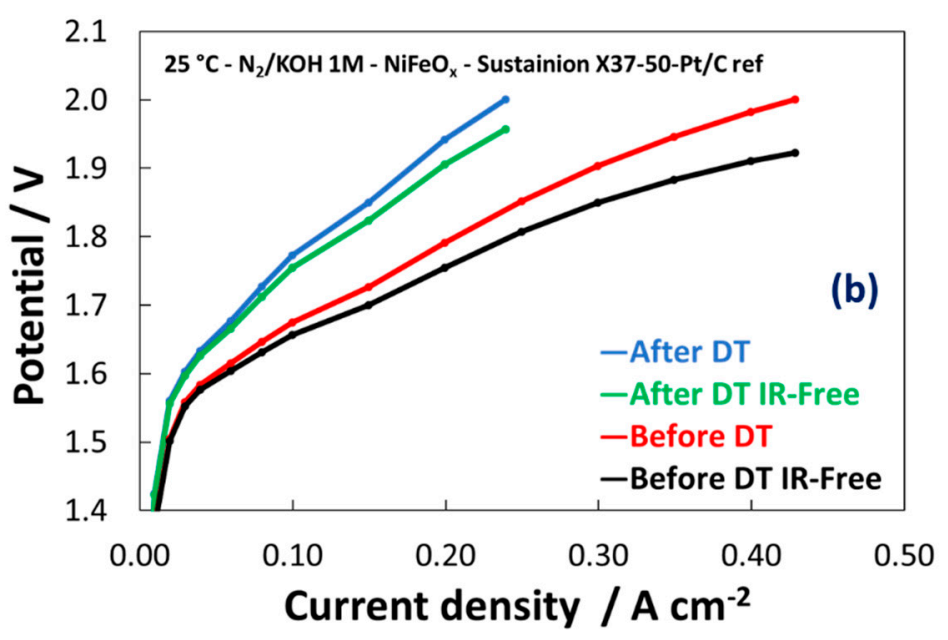

(b)

Figure 9. Potential cycling test $(1-1.8 \mathrm{~V})$ for the $\mathrm{NiFeO}_{\mathrm{x}} \mathrm{KB}(1: 1)$ catalyst with the Sustainion ${ }^{\mathrm{TM}}$ membrane in $1 \mathrm{M} \mathrm{KOH} \mathrm{(a)} \mathrm{and} \mathrm{polarization} \mathrm{curves} \mathrm{for} \mathrm{the} \mathrm{NiFeO}_{\mathrm{x}} \mathrm{KB}$ 70:30 catalyst based MEA before and after the accelerated stress test $(\mathbf{b})$.

Therefore, based on these preliminary experiments, the $\mathrm{NiFeO}_{x}$ used for the OER needs to be improved especially in terms of stability under operation in alkaline conditions. This may be related to the excess of $\mathrm{NiO}$ compared to the spinel phase in the catalyst. A spinel structure is usually considered a robust option but the performance observed for the present $\mathrm{NiFe}_{2} \mathrm{O}_{\mathrm{x}}$ needs to be ameliorated. An important aspect that requires further investigation is the effect of the crystallite size. The $\mathrm{NiFeO}_{x}$ shows larger crystallite size compared the $\mathrm{NiFe}_{2} \mathrm{O}_{x}(10 \mathrm{~nm}$ vs $5 \mathrm{~nm})$. The OER is a structure sensitive reaction and its rate can be enhanced by modulating lattice characteristics. Tailoring composition and crystallographic properties may be also relevant to provide better stability under dynamic conditions.

\section{Conclusions}

Critical raw materials-free catalysts are a key topic to develop electrochemical technologies for hydrogen generation. In this regard, alkaline solid membrane-based electrolysers represent an interesting technology. Although Ni-Fe based materials are largely investigated as electrodes for OER reaction, further enhancements are still necessary in terms of composition, stability and facile synthesis methods for their preparation and utilisation in practical devices. In this paper, a simple method for the synthesis of two compositions of NiFe based materials (i.e., $\mathrm{Ni} F \mathrm{Fe}=1: 1$ and 1:2) was presented. These two materials were treated at the same temperature (i.e., $450{ }^{\circ} \mathrm{C}$ ) showing different structures and surface compositions. The increased content of Fe affected the crystallinity and the occurrence of a spinel phase in the final electrocatalyst. A larger occurrence of the spinel phase on the surface of the catalyst containing a higher Fe content (i.e., $\mathrm{NiFe}_{2} \mathrm{O}_{\mathrm{x}}$ ) has been observed. As a result of the electrochemical tests, the increased content of $\mathrm{NiO}$ on the $\mathrm{NiFeO}_{\mathrm{x}}$ electrocatalyst surface positively affects the OER reaction rate. However, the electrochemical stress test consisting in a cycle (1-1.8 V) operation showed that the MEA based on $\mathrm{NiFeO}_{x}$ was not sufficiently stable within the time investigated $(500 \mathrm{~h})$. Further efforts in preparing NiFe-based catalysts should be addressed to improve the composition of the catalyst's surface and to modulate crystallographic properties and chemical characteristics.

Author Contributions: Conceptualization, A.S.A. and S.C.Z.; methodology, A.S.A. and S.C.Z.; software, S.T.; analysis, S.C.Z. and M.L.F.; investigation, S.C.Z.; writing-original draft preparation, S.C.Z., M.L.F and A.S.A..; writing-review and editing, S.C.Z., M.L.F. and A.S.A.; project administration, A.S.A.; funding acquisition, A.S.A. All authors have read and agreed to the published version of the manuscript. 
Funding: This research was funded by the EU H2020 LOTERCO2M project "CRM-free Low Temperature Electrochemical Reduction of CO2 to Methanol" Grant Agreement number: 761093.

Conflicts of Interest: The authors declare no conflict of interest.

\section{References}

1. Vincent, I.; Bessarabov, D. Low cost hydrogen production by anion exchange membrane electrolysis: A review. Renew. Sustain. Energy Rev. 2018, 81, 1690-1704. [CrossRef]

2. Holladay, J.; Hu, J.; King, D.; Wang, Y. An overview of hydrogen production technologies. Catal. Today 2009, 139, 244-260. [CrossRef]

3. Santo, V.D.; Gallo, A.; Naldoni, A.; Guidotti, M.; Psaro, R. Bimetallic heterogeneous catalysts for hydrogen production. Catal. Today 2012, 197, 190-205. [CrossRef]

4. Ferrero, D.; Lanzini, A.; Santarelli, M.; Leone, P. A comparative assessment on hydrogen production from low- and high-temperature electrolysis. Int. J. Hydrog. Energy 2013, 38, 3523-3536. [CrossRef]

5. Faro, M.L.; Trocino, S.; Zignani, S.; Antonucci, V.; Aricò, A. Production of syngas by solid oxide electrolysis: A case study. Int. J. Hydrog. Energy 2017, 42, 27859-27865. [CrossRef]

6. Dionigi, F.; Strasser, P. NiFe-Based (Oxy)hydroxide Catalysts for Oxygen Evolution Reaction in Non-Acidic Electrolytes. Adv. Energy Mater. 2016, 6, 1600621. [CrossRef]

7. Schalenbach, M.; Tjarks, G.; Carmo, M.; Lueke, W.; Mueller, M.; Stolten, D. Acidic or Alkaline? Towards a New Perspective on the Efficiency of Water Electrolysis. J. Electrochem. Soc. 2016, 163, F3197-F3208. [CrossRef]

8. Bandal, H.; Jadhav, V.H.; Kim, H. Facile synthesis of bicontinuous Ni3Fe alloy for efficient electrocatalytic oxygen evolution reaction. J. Alloy. Compd. 2017, 726, 875-884. [CrossRef]

9. Liu, Z.; Sajjad, S.D.; Gao, Y.; Kaczur, J.; Masel, R. An Alkaline Water Electrolyzer with Sustainion ${ }^{\mathrm{TM}}$ Membranes: $1 \mathrm{~A} / \mathrm{cm}^{2}$ at $1.9 \mathrm{~V}$ with Base Metal Catalysts. ECS Trans. 2017, 77, 71-73. [CrossRef]

10. Hwang, G.-J.; Gil, B.-M.; Ryu, C.-H. Preparation of the electrode using NiFe 2 O 4 powder for the alkaline water electrolysis. J. Ind. Eng. Chem. 2017, 48, 242-248. [CrossRef]

11. Phillips, R.; Gannon, W.J.F.; Dunnill, C.W. Chapter 2: Alkaline electrolysers. In RSC Energy and Environment Series; Royal Society of Chemistry (RSC): London, UK, 2020; Volume 2020-January, pp. 28-58.

12. Dekel, D.R. Review of cell performance in anion exchange membrane fuel cells. J. Power Sources 2018, 375, 158-169. [CrossRef]

13. Takenaka, H.; Torikai, E.; Kawami, Y.; Wakabayashi, N. Solid polymer electrolyte water electrolysis. Int. J. Hydrog. Energy 1982, 7, 397-403. [CrossRef]

14. Millet, P.; Andolfatto, F.; Durand, R. Design and performance of a solid polymer electrolyte water electrolyzer. Int. J. Hydrog. Energy 1996, 21, 87-93. [CrossRef]

15. Leroy, R. Industrial water electrolysis: Present and future. Int. J. Hydrog. Energy 1983, 8, 401-417. [CrossRef]

16. Lu, P.W.T.; Srinivasan, S. Advances in water electrolysis technology with emphasis on use of the solid polymer electrolyte. J. Appl. Electrochem. 1979, 9, 269-283. [CrossRef]

17. Carmo, M.; Fritz, D.L.; Mergel, J.; Stolten, D. A comprehensive review on PEM water electrolysis. Int. J. Hydrog. Energy 2013, 38, 4901-4934. [CrossRef]

18. Busacca, C.; Zignani, S.C.; Di Blasi, A.; Di Blasi, O.; Faro, M.L.; Antonucci, V.; Aricò, A. Electrospun NiMn2O4 and $\mathrm{NiCo} 2 \mathrm{O} 4$ spinel oxides supported on carbon nanofibers as electrocatalysts for the oxygen evolution reaction in an anion exchange membrane-based electrolysis cell. Int. J. Hydrog. Energy 2019, 44, 20987-20996. [CrossRef]

19. Couture, G.; Alaaeddine, A.; Boschet, F.; Améduri, B. Polymeric materials as anion-exchange membranes for alkaline fuel cells. Prog. Polym. Sci. 2011, 36, 1521-1557. [CrossRef]

20. Danks, T.N.; Slade, R.; Varcoe, J.R. Alkaline anion-exchange radiation-grafted membranes for possible electrochemical application in fuel cells. J. Mater. Chem. 2003, 13, 712-721. [CrossRef]

21. Tsai, T.-H.; Maes, A.M.; Vandiver, M.A.; Versek, C.; Seifert, S.; Tuominen, M.; Liberatore, M.W.; Coughlin, E.B. Synthesis and structure-conductivity relationship of polystyrene- block -poly(vinyl benzyl trimethylammonium) for alkaline anion exchange membrane fuel cells. J. Polym. Sci. Part B: Polym. Phys. 2012, 51, 1751-1760. [CrossRef] 
22. Morandi, C.; Peach, R.; Krieg, H.; Kerres, J. Novel imidazolium-functionalized anion-exchange polymer PBI blend membranes. J. Membr. Sci. 2015, 476, 256-263. [CrossRef]

23. Aili, D.; Kraglund, M.R.; Tavacoli, J.; Chatzichristodoulou, C.; Jensen, J.O. Polysulfone-polyvinylpyrrolidone blend membranes as electrolytes in alkaline water electrolysis. J. Membr. Sci. 2020, 598, 117674. [CrossRef]

24. Kim, D.J.; Lee, B.-N.; Nam, S.Y. Synthesis and characterization of PEEK containing imidazole for anion exchange membrane fuel cell. Int. J. Hydrog. Energy 2017, 42, 23759-23767. [CrossRef]

25. Davydova, E.S.; Mukerjee, S.; Jaouen, F.; Dekel, D.R. Electrocatalysts for Hydrogen Oxidation Reaction in Alkaline Electrolytes. ACS Catal. 2018, 8, 6665-6690. [CrossRef]

26. Massari, S.; Ruberti, M. Rare earth elements as critical raw materials: Focus on international markets and future strategies. Resour. Policy 2013, 38, 36-43. [CrossRef]

27. Di Vona, M.L.; Narducci, R.; Pasquini, L.; Pelzer, K.; Knauth, P. Anion-conducting ionomers: Study of type of functionalizing amine and macromolecular cross-linking. Int. J. Hydrog. Energy 2014, 39, 14039-14049. [CrossRef]

28. Di Blasi, A.; D’Urso, C.; Baglio, V.; Antonucci, V.; Arico, A.S.; Ornelas, R.; Matteucci, F.; Orozco, G.; Beltran, D.; Meas, Y.; et al. Preparation and evaluation of $\mathrm{RuO}_{2}-\mathrm{IrO}_{2}, \mathrm{IrO}_{2}-\mathrm{Pt}$ and $\mathrm{IrO}_{2}-\mathrm{Ta}_{2} \mathrm{O}_{5}$ catalysts for the oxygen evolution reaction in an SPE electrolyzer. J. Appl. Electrochem. 2008, 39, 191-196. [CrossRef]

29. McCrory, C.C.L.; Jung, S.; Peters, J.C.; Jaramillo, T.F. Benchmarking Heterogeneous Electrocatalysts for the Oxygen Evolution Reaction. J. Am. Chem. Soc. 2013, 135, 16977-16987. [CrossRef]

30. Benrabaa, R.; Boukhlouf, H.; Löfberg, A.; Rubbens, A.; Rose-Noëlle, V.; Bordes-Richard, E.; Barama, A. Nickel ferrite spinel as catalyst precursor in the dry reforming of methane: Synthesis, characterization and catalytic properties. J. Nat. Gas Chem. 2012, 21, 595-604. [CrossRef]

31. Gong, M.; Dai, H. A mini review of NiFe-based materials as highly active oxygen evolution reaction electrocatalysts. Nano Res. 2014, 8, 23-39. [CrossRef]

32. Pérez-Alonso, F.; Adán, C.; Rojas, S.; Peña, M.A.; Jose, F. Ni/Fe electrodes prepared by electrodeposition method over different substrates for oxygen evolution reaction in alkaline medium. Int. J. Hydrog. Energy 2014, 39, 5204-5212. [CrossRef]

33. Huang, L.; Ge, X.; Dong, S. A facile conversion of a Ni/Fe coordination polymer to a robust electrocatalyst for the oxygen evolution reaction. RSC Adv. 2017, 7, 32819-32825. [CrossRef]

34. Yang, Y.; Dang, L.; Shearer, M.; Sheng, H.; Li, W.; Chen, J.; Xiao, P.; Zhang, Y.; Hamers, R.J.; Jin, S. Highly Active Trimetallic NiFeCr Layered Double Hydroxide Electrocatalysts for Oxygen Evolution Reaction. Adv. Energy Mater. 2018, 8, 1703189. [CrossRef]

35. Fan, H.; Chen, W.; Chen, G.; Huang, J.; Song, C.; Du, Y.; Li, C.; Ostrikov, K.K. Plasma-heteroatom-doped $\mathrm{Ni}-\mathrm{V}-\mathrm{Fe}$ trimetallic phospho-nitride as high-performance bifunctional electrocatalyst. Appl. Catal. B: Environ. 2019, 268, 118440. [CrossRef]

36. Qin, F.; Zhao, Z.; Alam, K.; Ni, Y.; Hernandez, F.C.R.; Yu, L.; Chen, S.; Ren, Z.; Wang, Z.; Bao, J. Trimetallic NiFeMo for Overall Electrochemical Water Splitting with a Low Cell Voltage. ACS Energy Lett. 2018, 3, 546-554. [CrossRef]

37. Chanda, D.; Hnát, J.; Paidar, M.; Bouzek, K. Evolution of physicochemical and electrocatalytic properties of $\mathrm{NiCO}_{2} \mathrm{O}_{4}\left(\mathrm{AB}_{2} \mathrm{O}_{4}\right)$ spinel oxide with the effect of Fe substitution at the A site leading to efficient anodic $\mathrm{O}_{2}$ evolution in an alkaline environment. Int. J. Hydrog. Energy 2014, 39, 5713-5722. [CrossRef]

38. Pebley, A.; Decolvenaere, E.; Pollock, T.; Gordon, M. Oxygen evolution on Fe-doped NiO electrocatalysts deposited: Via microplasma. Nanoscale 2017, 9, 15070-15082. [CrossRef]

39. Paulraj, A.R.; Kiros, Y.; Göthelid, M.; Johansson, M.B. $\mathrm{NiFeO}_{\mathrm{x}}$ as a bifunctional electrocatalyst for oxygen reduction (OR) and evolution (OE) reaction in alkaline media. Catalysts 2018, 8, 328. [CrossRef]

40. Lo Faro, M.; Frontera, P.; Antonucci, P.; Aricò, A.S. Ni-Cu based catalysts prepared by two different methods and their catalytic activity toward the ATR of methane. Chem. Eng. Res. Des. 2015, 93, 269-277. [CrossRef]

41. Zignani, S.C.; Antolini, E.; Gonzalez, E.R. Stability of Pt-Ni/C (1:1) and Pt/C electrocatalysts as cathode materials for polymer electrolyte fuel cells: Effect of ageing tests. J. Power Sources 2009, 191, 344-350. [CrossRef]

42. Linares, J.J.; Zignani, S.C.; Rocha, T.A.; Gonzalez, E.R. Ethanol oxidation on a high temperature PBI-based DEFC using $\mathrm{Pt} / \mathrm{C}, \mathrm{PtRu} / \mathrm{C}$ and $\mathrm{Pt}_{3} \mathrm{Sn} / \mathrm{C}$ as catalysts. J. Appl. Electrochem. 2013, 43, 147-158. [CrossRef] 
43. Friebel, D.; Louie, M.W.; Bajdich, M.; Sanwald, K.E.; Cai, Y.; Wise, A.M.; Cheng, M.J.; Sokaras, D.; Weng, T.C.; Alonso-Mori, R.; et al. Identification of highly active Fe sites in (Ni,Fe)OOH for electrocatalytic water splitting. J. Am. Chem. Soc. 2015, 137, 1305-1313. [CrossRef] [PubMed]

44. Landon, J.; Demeter, E.; Inoğlu, N.; Keturakis, C.; Wachs, I.E.; Vasić, R.; Frenkel, A.I.; Kitchin, J.R. Spectroscopic characterization of mixed Fe-Ni oxide electrocatalysts for the oxygen evolution reaction in alkaline electrolytes. ACS Catal. 2012, 2, 1793-1801. [CrossRef]

45. Fominykh, K.; Chernev, P.; Zaharieva, I.; Sicklinger, J.; Stefanic, G.; Döblinger, M.; Müller, A.; Pokharel, A.; Böcklein, S.; Scheu, C.; et al. Iron-doped nickel oxide nanocrystals as highly efficient electrocatalysts for alkaline water splitting. ACS Nano 2015, 9, 5180-5188. [CrossRef] [PubMed]

46. Han, G.Q.; Liu, Y.R.; Hu, W.H.; Dong, B.; Li, X.; Shang, X.; Chai, Y.M.; Liu, Y.Q.; Liu, C.G. Three dimensional nickel oxides/nickel structure by in situ electro-oxidation of nickel foam as robust electrocatalyst for oxygen evolution reaction. Appl. Surf. Sci. 2015, 359, 172-176. [CrossRef]

47. Liu, J.; Zhu, D.; Ling, T.; Vasileff, A.; Qiao, S.Z. S- $-\mathrm{NiFe}_{2} \mathrm{O}_{4}$ ultra-small nanoparticle built nanosheets for efficient water splitting in alkaline and neutral pH. Nano Energy 2017, 40, 264-273. [CrossRef]

48. Jiang, J.; Zhang, C.; Ai, L. Hierarchical iron nickel oxide architectures derived from metal-organic frameworks as efficient electrocatalysts for oxygen evolution reaction. Electrochimica Acta 2016, 208, 17-24. [CrossRef]

49. Fang, J.; Hu, L.; Wang, M.; Gan, L.; Chen, C.; Jiang, Y.; Xiao, B.; Lai, Y.; Li, J. NiO-Fe ${ }_{2} \mathrm{O}_{3} /$ carbon nanotubes composite as bifunctional electrocatalyst for rechargeable Zn-air batteries. Mater. Lett. 2018, 218, 36-39. [CrossRef]

50. Wang, J.; Zuo, S.; Wei, G.; Niu, Y.; Guo, L.; Chen, Z. Investigation of Fe-based integrated electrodes for water oxidation in neutral and alkaline solutions. J. Phys. Chem. C 2019, 123, 12313-12320. [CrossRef]

51. Pushkareva, I.V.; Pushkarev, A.S.; Grigoriev, S.A.; Modisha, P.; Bessarabov, D.G. Comparative study of anion exchange membranes for low-cost water electrolysis. Int. J. Hydrog. Energy 2019. [CrossRef]

52. Arges, C.G.; Zhang, L. Anion exchange membranes' evolution toward high hydroxide ion conductivity and alkaline resiliency. ACS Appl. Energy Mater. 2018, 1, 2991-3012. [CrossRef]

53. Hickner, M.A.; Herring, A.M.; Coughlin, E.B. Anion exchange membranes: Current status and moving forward. J. Polym. Sci. Part B: Polym. Phys. 2013, 51, 1727-1735. [CrossRef]

54. Li, N.; Leng, Y.; Hickner, M.A.; Wang, C.Y. Highly stable, anion conductive, comb-shaped copolymers for alkaline fuel cells. J. Am. Chem. Soc. 2013, 135, 10124-10133. [CrossRef] [PubMed]

55. Mamlouk, M.; Manolova, M. Chapter 6: Alkaline anionic exchange membrane water electrolysers. In RSC Energy and Environment Series; Royal Society of Chemistry (RSC): London, UK, 2020; Volume 2020-January, pp. 180-252.

(C) 2020 by the authors. Licensee MDPI, Basel, Switzerland. This article is an open access article distributed under the terms and conditions of the Creative Commons Attribution (CC BY) license (http://creativecommons.org/licenses/by/4.0/). 